\title{
RANCANGAN VFR CORRIDOR MAJALENGKA CONTROL ZONE DI PERUM LPPNPI UNIT PELAYANAN KERTAJATI
}

\author{
Ryan Dirgantara Hasibuan ${ }^{(1)}$, Lina Rosmayanti ${ }^{(2)}$, Agus Setiawan ${ }^{(3)}$ \\ ${ }^{1,2,3}$ Politeknik Penerbangan Indonesia Curug \\ e-mail: ${ }^{1}$ ryan.hasibuan@ ppicurug.ac.id, ${ }^{2}$ lina.rosmayanti@ ppicurug.ac.id \\ ${ }^{3}$ agus.setiawan@ppicurug.ac.id
}

\begin{abstract}
Abstrak: Penelitian ini bertujuan membuat rancangan VFR Corridor yang menghubungkan Bandara Cakrabhuwana Cirebon, Bandara Tunggul Wulung Cilacap dan Bandara Cijulang Nusawairu. Metode penelitian berupa Research and Development dalam pengembangan level satu dengan pendekatan secara kualitatif dan pemaparan secara deskriptif. Teknik pengumpulan data berupa wawancara, studi literature, dan studi dokumentasi. Teknik pengolahan data menggunakan reduksi data, penyajian data, dan verifikasi. Berdasarkan data yang dikumpulkan, diketahui informasi bahwa penerbangan dari Cirebon menuju Cilacap dan Nusawiru tidak memiliki VFR Corridor yang jelas, sedangkan jumlah traffic overflying yang melakukan penerbangan Cross Country menuju bandara tersebut tergolong banyak.
\end{abstract}

Kata Kunci: Air Traffic Controller, Research and Development, VFR Corridor.

Abstract: This study aims to design VFR Corridor connecting Cakrabhuwana Airport in Cirebon with Tunggul Wulung Cilacap Airport and Cijulang Nusawairu Airport.The research method used is level one research and development with a qualitative approach and descriptive exposure. Data collection techniques in the form of interviews, literature studies, and documentation studies. Meanwhile, data processing techniques use data reduction, data presentation, and verification. Based on the data collected, it is known that the flights from Cirebon to Cilacap and Nusawiru or vice versa do not have a clear VFR Corridor to connect the three airports, while the number of traffic overflying that makes Cross Country flights to Tunggul Wulung Cilacap and Cijulang Nusawiru airports is quite large.

Keyword: $\quad$ Air Traffic Controller, Research and Development, VFR Corridor.

http://journal.ppicurug.ac.id/index.php/jurnal-langit-biru 
Rancangan VFR Corridor Majalengka Control Zone di Perum LPPNPI Unit Pelayanan Kertajati

\section{Pendahuluan}

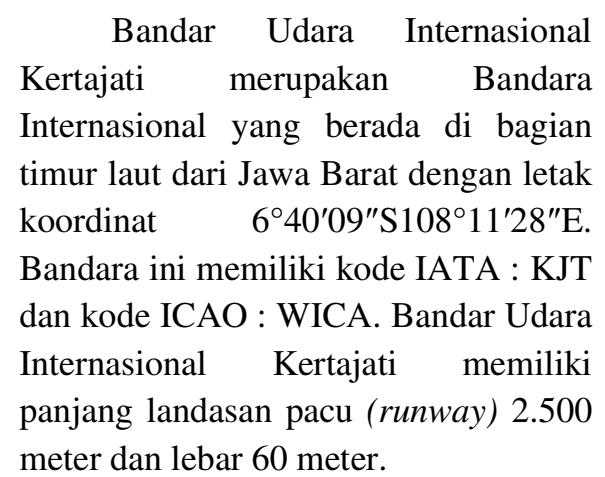

Berdasarkan AIRAC AIP SUPLEMENT Nr. 10/18 tanggal 29 Maret 2018, Bandara yang terletak 22 km dari Kota Majalengka ini lebih dikenal dengan nama Bandara Internasional Jawa Barat (BIJB) mulai beroperasi mulai tanggal 24 Mei 2018. Hal ini di tandai dengan adanya historical flight pesawat kepresidenan B737-800 yang landing pada pukul 09.30 waktu setempat.

Berdasarkan AIRAC AIP SUPLEMENT Nr. 09/18 tanggal 29 Maret 2018, ruang udara milik Bandara Cakrabhuwana Cirebon yang melayani Training Flight bagi para calon pilot dari berbagai Flying School beralih menjadi tanggung jawab unit Kertajati Tower, sehingga pergerakan lalu lintas udara semakin beragam yaitu di mulai dari pesawat on schedule, over flying dan training flight.

Majalengka CTR memiliki klasifikasi ruang udara kelas $\mathrm{C}$, dimana penerbangan IFR dan penerbangan VFR diperbolehkan dan diberikan pelayanan lalu lintas udara, penerbangan IFR diberikan separasi dengan penerbangan IFR dan penerbangan VFR, serta penerbangan VFR diberikan separasi dengan penerbangan IFR dan diberikan traffic information dengan penerbangan VFR.

Perum LPPNPI Kantor Unit Pelayanan Kertajati memberikan pelayanan berupa pengendalian dan pengawasan keselamatan penerbangan di wilayah Aerodrome Control Tower (TWR) dan Approach Control Service (APP) secara combine unit.

Dengan jumlah traffic (arus lalu lintas udara) sebanyak 40-50 pergerakan di Majalengka Control Zone per harinya (Data Traffic Movement TWR Kertajati). Sehingga volume penerbangan di bandara ini cukup terbilang banyak terlebih di bandara tersebut terdapat pula sekolah pilot swasta yaitu AAA (Angkasa Aviation Academy), Alfa Flying School, ProFlight, AeroFlyer, Global Aviation.

Dari hasil pengamatan penulis selama mengikuti kegiatan On the Job Training, penulis melihat secara langsung petugas ATC Unit Pelayanan Kertajati mengalami masalah dalam melakukan pemanduan lalu lintas penerbangan dimana terdapat ketidak jelasan pesawat Cross Country dalam melakukan reporting position yang berasal dari Cirebon menuju Cilacap , Budiarto menuju Cilacap, Cilacap menuju Nusawiru dan Nusawiru menuju Nusawiru (WICD-WAHL, WIRR-WAHL,WAHL-WICN dan WICN-WICN),

Hal tersebut terjadi apabila penerbangan Cross Country yang berada di rute penerbangan dengan tujuan bandara yaitu Tunggul Wulung Cilacap dan Cijulang Nusawiru, akan mengalami pertemuan antara kedua pesawat yang dari ataupun menuju bandara tersebut, peristiwa ini 
disebabkan karena rute setelah melewati losari, tegal dan CA NDB belum di tetapkan dengan jelas.

Perum LPPNPI Unit Pelayanan Kertajati memberikan pelayanan pemanduan Air Traffic Services kepada pesawat Training Flight dengan jenis penerbangan Cross Country dari setiap sekolah penerbangan swasta, di dalam wilayah Majalengka Control Zone

Sekolah penerbangan swasta melakukan penerbangan Cross Country secara VFR dengan kondisi sekarang yang terjadi, pesawat tersebut terbang dengan menentukan patokan / check point sendiri pada setiap rute yang di lewatinya sehingga effisiensi pergerakan pesawat udara yang tidak dapat di prediksi dan keselamatan penerbangan yang dapat terancam ini dapat menyebabkan petugas ATC mengalami kesulitan dalam pemberian pelayanan pemanduan lalu lintas penerbangan dengan maksimal.

Hal ini akan menambah beban petugas ATC, bahkan dapat menimbulkan potensi incident bagi pesawat yang terbang secara bebas, karena petugas ATC mendapatkan kendala dalam penentuan posisi pesawat yang terbang dengan rute Cross Country tersebut.

Untuk menghindari terjadinya konflik pada traffic Cross Country tersebut, personel Air Traffic Controller yang bertugas, sementara menyelesaikannya dengan menggunakan teknik control masingmasing yaitu dengan mempertahankan separasi vertical antar pesawat dengan reporting position berdasarkan radial yang di ukur dari CA NDB sebagai acuannya.
Dimana pemecahan permasalahan traffic menggunakan teknik control oleh ATC tersebut tidak cukup dilakukan untuk mencegah terjadinya konflik yang dapat membahayakan lalu lintas penerbangan, di karenakan ketidak pastian rute yang di lewati oleh pilot tersebut.

\section{Metode}

Dalam metode penelitian ini peneliti menggunakan Research and Development (R\&D Level 1. Menurut Sugiyono (2018) Penelitian R\&D Level 1 yaitu peneliti melakukan penelitian untuk menghasilkan rancangan, tetapi tidak dilanjutkan dengan membuat produk dan mengujinya.

Tingkatan (level) penelitian dan pengembangan yang akan dilakukan yaitu level satu dimana penulis akan meneliti dan menghasilkan rancangan, tetapi tidak memproduksi dan tidak mengujinya. Langkah - langkahnya adalah sebagai berikut:

a. Perumusan masalah (melalui studi kelayakan);

b. Studi literatur (kepustakaan) dan penelitian;

c. Perancangan produk;

d. Validasi hasil rancang;

e. Rancangan sudah teruji

\section{Metode Pengumpulan Data}

Pada penelitian ini, penulis menggunakan beberapa teknik pengumpulan data dalam mengumpulkan data yang diperlukan, yaitu: 
Rancangan VFR Corridor Majalengka Control Zone di Perum LPPNPI Unit Pelayanan Kertajati

a. Wawancara

Wawancara adalah teknik
pengambilan data dengan mengajukan pertanyaan langsung oleh pewawancara kepada narasumber, jawaban dari responden dicatat atau di rekam. Penulis juga melakukan wawancara menggunakan social media seperti whatsapp. Penulis melakukan wawancara tak berstruktur pada tahap penelitian rancangan, yang dimulai dari pembahasan terkait masalah di lapangan sampai dengan bentuk penyelesaian masalah yang tepat.

\section{b. Observasi Lapangan}

Observasi adalah kegiatan untuk melakukan pengukuran atau pencatatan data dimana peneliti tidak mengajukan pertanyaan melainkan melalui panca indera (Aminarno:2019).

Teknik pengumpulan observasi ini bersifat fleksibel, dengan arti peneliti dapat mengumpulkan data di lapangan secara bebas, kapanpun penulis dapat mengumpulkan data lagi guna menunjang kelengkapan data pada proposal.

\section{c. Studi Dokumentasi}

Studi Dokumentasi adalah pengumpulan informasi dan data dengan bantuan berbagai macam material yang ada di lapangan seperti data penerbangan berupa strip, catatan, kisah-kisah sejarah dan sebagainya. Tujuan Studi Dokumentasi adalah untuk mendapatkan landasan teori yang dapat dijadikan pedoman pemecahan masalah dan dapat menghindari penelitian terhadap aspek-aspek dugaan dari suatu permasalahan yang telah diteliti sebelumnya. Teknik studi dokumentasi digunakan untuk melakukan pengumpulan data dengan jenis data sekunder.

\section{d. Studi Literatur}

Studi Literatur adalah teknik pengumpulan data yang tidak langsung di tujukan kepada subjek penelitian (Aminarno:2019). Peneliti melakukan teknik pengumpulan data dan informasi melalui dokumen-dokumen ICAO dan AirNav Indonesia, Peraturan Pemerintah, Data Schedule Flight, arsip data penerbangan, chart dan literatureliteratur yang relevan dengan masalah penelitian.

\section{Metode Analisis Data}

Analisis data merupakan suatu proses penyederhanaan data ke dalam bentuk yang lebih mudah dibaca dan diinterpretasikan. Dalam penelitian ini, penulis menggunakan teknik analisis data kualitatif, dimana teknik analisis data terdiri dari tahapan berikut:

\section{a. Reduksi Data}

Reduksi data merupakan proses pemilihan, penyederhanaan, pemusatan perhatian, serta transformasi data kasar yang muncul dari catatan penulis selama penelitian. Sehingga data yang sudah direduksi akan memberikan gambaran yang lebih jelas.

\section{b. Penyajian Data}

Setelah proses reduksi data, langkah selanjutnya adalah penulis melakukan penyajian data berupa teks yang bersifat uraian, dimana berfungsi untuk menggabungkan 
Informasi data sehingga mempermudah memahami apa yang sedang terjadi.

\section{c. Menarik Kesimpulan}

Kegiatan analisis selanjutnya adalah menarik kesimpulan dan verifikasi dimana berfungsi untuk mengetahui kebenaran rancangan penulis berdasarkan para ahli yang sudah ditentukan.

\section{Diskusi}

Berdasarkan hasil wawancara tidak terstruktur di atas yang diperoleh dari petugas ATC Perum LPPNPI Kantor Unit Kertajati, penulis mengetahui bahwa tidak tersedianya VFR route yang menghubungkan Bandar udara Cakrabhuwana Cirebon, Bandar udara Tunggul Wulung Cilacap dan Bandar udara Cijulang Nusawiru dapat menimbulkan potensi nearmiss antara pesawat Cross Country,

Pergerakan pesawat saat ini belum memiliki rute dan ground reference point yang pasti dengan terbang berdasarkan patokan patokan di daerah malahayu bantarkawung dan bulakamba untuk rute menuju Bandar udara Tunggul Wulung Cilacap dan patokan patokan di daerah sagara dan pangan untuk menuju Bandar udara Cijulang Nusawiru

Pada penelitian tahap dua, peneliti melakukan wawancara kepada personel ATC dilapangan yang dipercaya dalam bidang prosedur. Berdasarkan wawancara tersebut kemudian peneliti menarik kesimpulan di Majalengka Control Zone untuk penerbangan Cross Country perlu adanya VFR route dan kepastian separasi dengan jalur pesawat IFR yaitu SID Lacap 1A yang di lewati untuk menghubungkan langsung ketiga bandara yaitu Cakrabhuwana Cirebon, Tunggul Wulung Cilacap dan Cijulang Nusawiru dengan maksud untuk meningkatkan keselamatan penerbangan dan memenuhi effisiensi jarak serta waktu untuk pergerakan pesawat Cross Country

Dalam rancangan VFR route perlu adanya Ground Reference Point sebagai acuan pelaporan posisi dan ketinggian serta memastikan separasi yang aman dengan jalur SID Lacap $1 \mathrm{~A}$ guna membantu petugas ATC dalam memandu traffic yang berpotensi

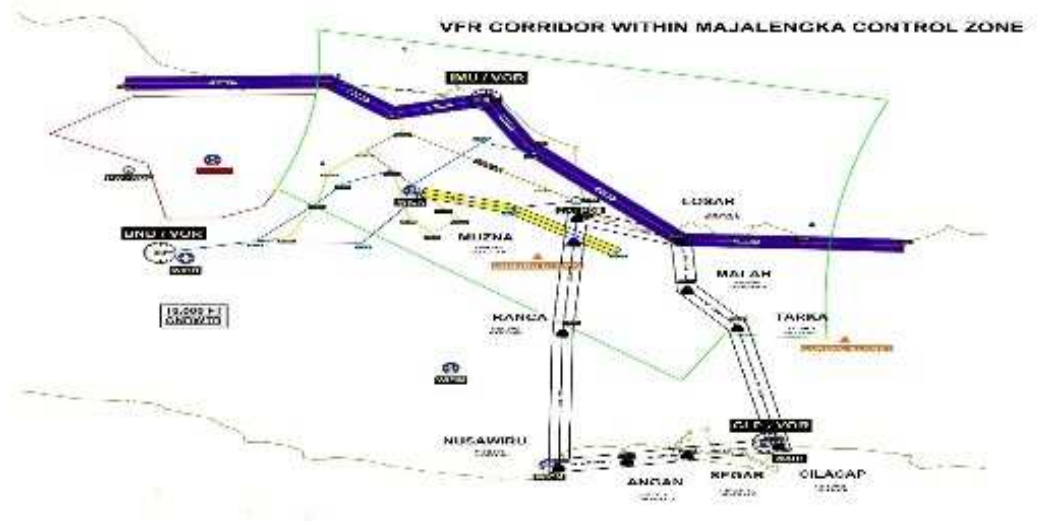

Gambar 2. Sirkulasi AC Sentral 
Rancangan VFR Corridor Majalengka Control Zone di Perum LPPNPI Unit Pelayanan Kertajati

bertemu dan membantu aksi cepat petugas ATC dalam melakukan penyelamatan jika terjadi abnormal situation.

Setelah melakukan wawancara pertama dan kedua, kemudian peneliti membuat rancangan VFR Route menggunakan aplikasi Autocad.

Kemudian rancangan tersebut diserahkan kepada validator untuk melakukan validasi rancangan. Indikator-indikator pembuatan VFR Route sudah terpenuhi dan ketiga pakar sebagai validator menyatakan rancangan VFR Route antara Bandar Udara Cakrabhuwana Cirebon, Tunggul Wulung Cilacap dan Cijulang Nusawiru layak untuk diterapkan

Kemudian rancangan tersebut diserahkan kepada validator untuk melakukan validasi rancangan. Indikator-indikator pembuatan VFR Route sudah terpenuhi dan ketiga pakar sebagai validator menyatakan rancangan VFR Route antara Bandar Udara Cakrabhuwana Cirebon, Tunggul Wulung Cilacap dan Cijulang Nusawiru layak untuk diterapkan.

\section{Kesimpulan}

1. Tidak tersedianya Rute dan Ground Reference Point yang menghubungkan Bandar udara Cakrabhuwana Cirebon, Tunggul Wulung Cilacap dan Cijulang Nusawiru menyebabkan keselamatan dan effisiensi lalu lintas penerbangan tidak terpenuhi karena ketidakjelasan posisi pesawat Flying School serta jarak rute yang di lewati pesawat Cross Country

2. Perum LPPNPI Kantor Unit Kertajati maupun instansi terkait belum mengadakan suatu kajian yang membahas tentang rute penerbangan Cross Country yang menghubungkan Cirebon, Cilacap dan Nusawiru.

3. Rancangan VFR route yang menghubungkan Bandar Udara Chakrabuana Cirebon, Tunggul wulung Cilacap dan Cijulang Nusawiru menggunakan kaidah pembuatan VFR Route yang sesuai dengan prosedur perancangan route penerbangan.

\section{Daftar Pustaka}

Aminarno Budi Pradana (2019). Metodologi Penelitian Ilmiah, Edisi Revisi Ke-3, Tangerang.

Hayuning Rizki Mahardita (2017). Efektivitas dan Efisiensi Kerja Aparatur Sipil Negara di Sekretariat DPRD Provinsi Kalimantan Timur.

Sugiyono, Prof., Dr (2015) Metode Penelitian Kuantitatif, Kualitatif, dan R\&D, Bandung : Alfabeta, 2015.

Sugiyono, Prof., Dr (2016) Metode Penelitian \& Pengambangan, Bandung : Alfabeta.

Perum LPPNPI Kantor Unit Kertajati (2018) $\quad$ Prosedur Operasi Standar Pelayanan Lalu Lintas Penerbangan, Tangerang: Perum LPPNPI.

Undang-undang Republik Indonesia Nomor 1 Tahun 2009 Tentang Penerbangan.

Peraturan Pemerintah Republik Indonesia Nomor 77 Tahun 2012 tentang Perusahaan Umum Lembaga Penyelenggara Pelayanan Navigasi Penerbangan Indonesia.

Peraturan Menteri Perhubungan Republik Indonesia Nomor PM 44 Tahun 2015 Tentang Peraturan Keselamatan Penerbangan Sipil Bagian 173 (Civil Aviation Safety Regulation Part 173) Prosedur 
Langit Biru: Jurnal Ilmiah Aviasi Vol. 14 No. 1 Februari 2021

ISSN (p) 1979-1534 ISSN (e) 2745-8695

Penerbangan (Flight Procedure Design)

Peraturan Menteri Perhubungan Republik Indonesia Nomor PM 55 Tahun 2016 Tentang Tatanan Navigasi Penerbangan Nasional

Peraturan Pemerintah Republik Indonesia Nomor 3 Tahun 2001 Tentang Keamanan dan Keselamatan Penerbangan.

Kementerian Perhubungan Republik Indonesia, Aeronautical Information Publication, Volume II dan Volume III.

Kementerian Perhubungan Republik Indonesia, AIRAC Aeronautical Information Publication Supplement, $\mathrm{Nr}$ : 10/18, The Operation of Kertajati International Airport, 2018.

Kementerian Perhubungan Republik Indonesia (2018). AIRAC Aeronautical Information Publication Supplement, $\mathrm{Nr}$ : 29/18, Restructuration of VFR Route Jakarta Area and Establishment of VFR Route in Northern Java Area.

Kementerian Perhubungan Republik Indonesia, PM Nomor 65 Tahun 2017 tentang Peraturan Keselamatan Penerbangan Sipil Bagian 170 (CASR 170) Tentang Peraturan Lalu Lintas Penerbangan (Air Traffic Rules).

International Civil Aviation Organization (1984), Doc. 9426AN/924, Air Traffic Services Planning Manual, First (Provisional) Edition.

International Civil Aviation Organization (2014). Doc. 8168OPS/611, Aircraft Operation Volume II, $6^{\text {th }}$ Edition.

International Civil Aviation Organization (2001). Annex 11, Air Traffic Services, $13^{\text {th }}$ Edition.

International Civil Aviation Organization, Doc. 9906-
AN/472, The Quality Assurance Manual For Flight Procedure Design Volume 2, Advance Edition. 